J. Dairy Sci. 92:5276-5291

doi:10.3168/jds.2009-2216

(c) American Dairy Science Association, 2009.

\title{
Bovine Muc1 is a highly polymorphic gene encoding an extensively glycosylated mucin that binds bacteria
}

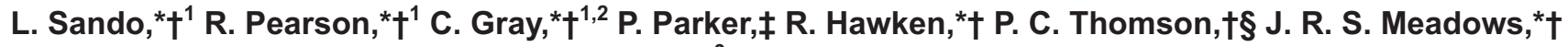 \\ K. Kongsuwan, ${ }^{*} \dagger$ S. Smith, $\ddagger$ and R. L. Tellam ${ }^{*} \dagger^{3}$ \\ ${ }^{*}$ CSIRO Livestock Industries, Queensland Bioscience Precinct, 306 Carmody Rd., St. Lucia, QLD 4067, Australia \\ †Co-operative Research Centre for Innovative Dairy Products (CRC-IDP), 84 William Street, Melbourne, Victoria 3000, Australia \\ ‡Deakin University, 225 Burwood Hwy, Burwood, Victoria 3151, Australia \\ §Centre for Advanced Technologies in Animal Genetics and Reproduction (ReproGen), University of Sydney, PMB3 Camden, New South Wales \\ 2570, Australia
}

\begin{abstract}
The bovine Muc1 protein is synthesized by mammary epithelial cells and shed into milk as an integral component of the milk fat globule membrane; however, the structure and functions of this mucin, particularly in relation to lactation, are poorly defined. The objectives of this investigation were to investigate the Muc1 gene and protein structures in the context of lactation and to test the hypothesis that Muc1 has a role in innate immune defense. Polymerase chain reaction analysis of genomic DNA from 630 cattle revealed extensive polymorphism in the variable number of tandem repeats (VNTR) in the bovine Muc1 gene. Nine allelic variants spanning 7 to 23 VNTR units, each encoding 20 AA, were identified. Three alleles, containing 11, 14, and 16 VNTR units, respectively, were predominant. In addition, a polymorphism in one of the VNTR units has the potential to introduce a unique site for N-linked glycosylation. Statistical analysis indicated weak associations between the VNTR alleles and milk protein and fat percentages in a progeny-tested population of Holstein-Friesian dairy cattle. No association with somatic cell count could be demonstrated. Bovine Muc1 was purified from milk fat globule membranes and characterized. The protein was highly glycosylated, primarily with O-linked sialylated T-antigen [Neu5Ac( $\alpha 2-3)-\operatorname{Gal}(\beta 1-3)-G a l N A c \alpha 1]$ and, to a lesser extent, with N-linked oligosaccharides, which together accounted for approximately $60 \%$ of the apparent mass of Muc1. Purified bovine Muc1 directly bound fluorescently labeled Escherichia coli BioParticles (Invitrogen, Mount Waverley, Australia) and inhibited their binding to bovine mammary epithelial cells grown in vitro.
\end{abstract}

\footnotetext{
Received March 16, 2009

Accepted June 16, 2009.

${ }^{1}$ Authors contributed equally to this research.

${ }^{2}$ Current address: School of Veterinary Science, University of Queensland, St. Lucia 4067, Australia.

${ }^{3}$ Corresponding author: ross.tellam@csiro.au
}

It was also demonstrated that the expression of $M u c 1$ mRNA in bovine mammary epithelial cells was markedly upregulated by lipopolysaccharide. Muc1 may be a pattern recognition protein that has the capacity to sequester bacteria and prevent their attachment to epithelial surfaces by immobilizing and subsequently shedding Muc1-bound bacteria from the cell surface. It was concluded that bovine Muc1 is probably an inducible innate immune effector and an important component of the first line of defense against bacterial invasion of epithelial surfaces, particularly mammary epithelial surfaces and the neonatal gut.

Key words: Muc1, mucin, polymorphism, innate immunity

\section{INTRODUCTION}

Muc1 is a type 1 membrane-bound mucin expressed by several epithelial tissues, including the mammary gland (Gendler, 2001). This glycoprotein is present on the apical plasma membrane of mammary epithelial cells and is subsequently shed into milk as a component of the milk fat globule membrane (MFGM), which is typically found in the cream fraction of milk (Mather, 2000). Muc1 can be observed by electron microscopy as numerous, mostly radially oriented filaments protruding approximately 0.2 to $0.7 \mu \mathrm{m}$ from the membrane surface (Patton et al., 1995). These filaments correspond to the extracellular domain of Muc1, which is typically characterized by extensive O-linked glycosylation, the predominant architectural feature of Muc1.

In addition to providing hydration and lubrication at the epithelial surfaces, mammalian Muc1 may protect epithelial cell surfaces from invasive pathogenic microorganisms (Patton et al., 1995; DeSouza et al., 1999; Lillehoj et al., 2004). The mucin fraction from human MFGM inhibited adhesion of S-fimbriated Escherichia coli to buccal epithelial cells (Schroten et al., 1992), and bovine Muc1 inhibited infection of monkey kidney and human intestinal cell lines with a neuraminidasesensitive rotavirus strain (Kvistgaard et al., 2004). Per- 
(a) Gene

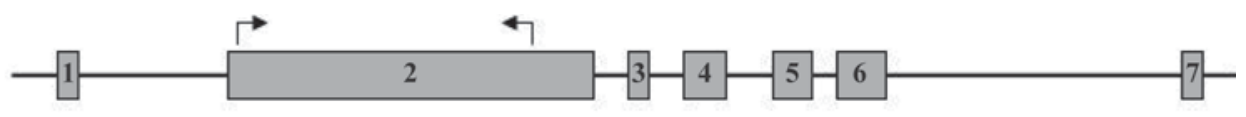

(b) Protein
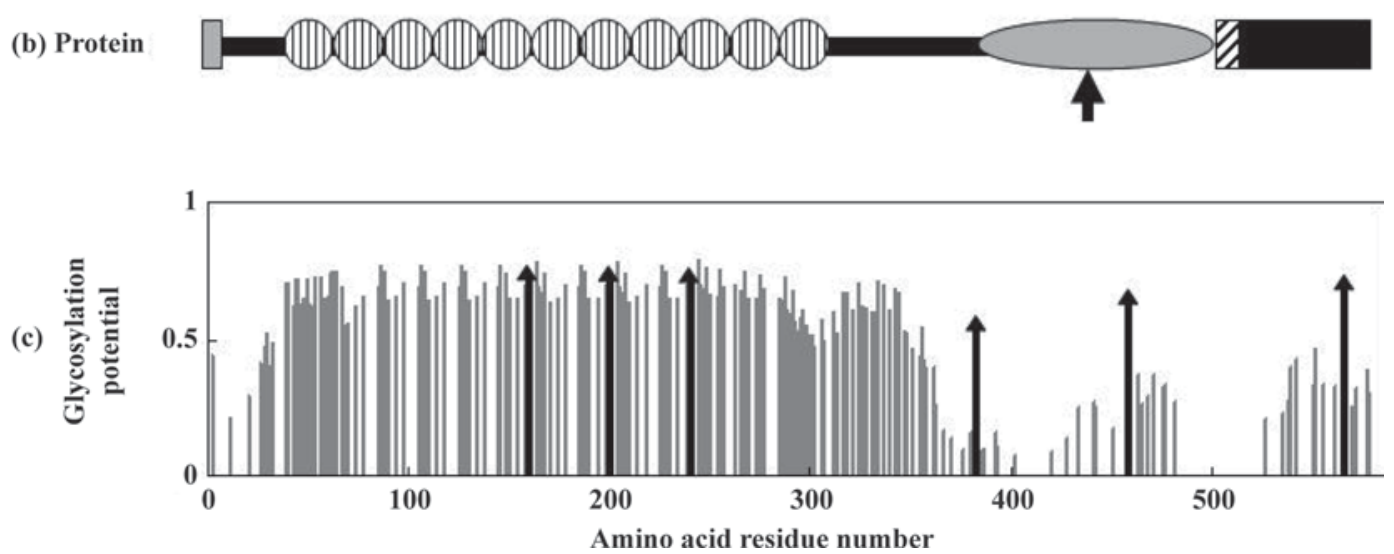

Figure 1. Schematic representation of the organization and protein structural domains of the bovine $M u c 1$ gene. The structures are based on the European Molecular Biology Laboratory Nucleotide Sequence Database, accession no. AJ400824, which possesses 11 variable number of tandem repeat (VNTR) units. (a) Gene organization. Exons are boxed and numbered. The genomic sequence was obtained from the Btau_4.0 assembly displayed on the University of California-Santa Cruz Genome Browser. Exon structure was deduced from the combination of the mRNA sequence (AJ400824) and the genomic sequence. The arrows indicate positions of PCR primers used to detect Muc1 polymorphisms. The gene spans 4.098 kb. (b) Muc1 protein domains. Signal peptide (gray box); VNTR domain (individual VNTR units are represented by vertically striped circles); SEA (initially identified in sperm protein, enterokinase, and agrin) module (gray oval); transmembrane domain (diagonally striped box); cytoplasmic domain (black). The translated protein sequence contains 580 AA. The potential proteolytic processing site is marked with an arrow. (c) Glycosylation potential. The bar graph shows the probabilities of glycosylation at predicted O- (gray lines) and N-linked (black lines capped with an arrow) glycosylation sites. Predictions were made using the NetOGlyc 3.1 (Julenius et al., 2005) and NetNGlyc 1.0 (Gupta et al., 2004) programs, respectively.

haps the most compelling evidence is the observation that the intestinal tracts of Muc1-deficient mice were more easily colonized by Helicobacter pylori and were associated with increased gastritis (McGuckin et al., 2007). Despite these investigations, very little is known about the functions of bovine Muc1 isolated from milk or the detailed nature of its gene and protein structures, especially considering the unusually low sequence conservation of the bovine protein.

The bovine Muc1 gene is characterized by 7 exons and the encoded protein consists of 5 structurally distinct domains: 1) the signal sequence; 2) the variable number of tandem repeats (VNTR) domain; 3) the SEA domain (initially identified in sperm protein, enterokinase, and agrin); 4) the transmembrane domain; and 5) the cytoplasmic domain (Figure 1; Gendler, 2001). The VNTR domain is encoded within exon 2 and can be polymorphic in some species. Each VNTR unit (20 AA) is predicted to be extensively glycosylated with O-linked oligosaccharides. The range in the number of VNTR units and the extent of VNTR polymorphism varies substantially across species, with no polymorphism in murine Muc1 and substantial VNTR polymorphisms in humans (21 to 125 VNTR units; Gendler, 2001). For bovine Muc1, up to 5 allelic variants, with VNTR ranging from 10 to 24 , have been suggested (DeSouza et al., 2007). The SEA domain in the human ortholog undergoes proteolytic processing, which can potentially lead to shedding of Muc1 from the cell surface (Levitin et al., 2005). However, the processed protein typically forms a stable noncovalently linked heterodimer. It is not known whether bovine Muc1 is similarly processed. The cytoplasmic domain is thought to be involved in signal transduction and protein-protein interactions (Gendler, 2001).

The objectives of this study were to investigate the extent of allelic polymorphisms in bovine Muc1 and their associations with dairy production traits. It was hypothesized that bovine Muc1 is extensively glycosylated with a predominance of simple O-linked oligosaccharides, and this was tested by measuring monosaccharide composition, lectin binding, and altered physical properties of Muc1 after neuraminidase treatment. The hypothesis that bovine Muc1 binds bacteria and prevents their attachment to bovine mammary epithelial cells (MEC) was also directly tested. 


\section{MATERIALS AND METHODS}

\section{Animal Sampling and DNA Extraction}

A total of 630 cattle were genotyped for Muc1 VNTR polymorphisms. Unless otherwise stated, DNA was extracted from white blood cells using the QIAamp DNA Mini Kit (Qiagen, Doncaster, Australia). Samples of 157 progeny-tested Holstein-Friesian bulls, selected from a population described elsewhere (Khatkar et al., 2006), were obtained by extraction of DNA from semen samples supplied by Genetics Australia (Bacchus Marsh, Australia; Khatkar et al., 2006). These animals were selected from the Australian Dairy Herd Improvement Scheme database based on EBV for high (78 animals; SCC EBV 4 to $53 \%$, mean $26 \%$, SD 9.2\%) and low (79 animals; SCC EBV -6 to $-42 \%$, mean $19.8 \%$, SD 6.7\%) SCC extremes. Further, samples from 263 Holstein-Friesian dairy cows were obtained from a research herd at the University of Sydney (Camden Research Centre, Camden, Australia). These cows had a mean age of $3.9 \mathrm{yr}$ and had calved within the last 1 to $2 \mathrm{yr}$, with DIM of 1 to 100 (51 cows), 101 to 200 (100 cows), 201 to 300 (68 cows), and >300 (44 cows). Within the Holstein-Friesian animals, only Muc1 alleles D, E, and G were identified. Another set of samples from 184 dairy cows representing a range of breeds and crossbreeds, as described elsewhere (Barendse et al., 2009), was obtained from 5 dairy farms in Queensland (Australia). These cows included Brown Swiss (4 cows), Holstein-Friesian (52), Brown Swiss Holstein (26), Guernsey (4), Jersey (10), Guernsey Holstein (2), Holstein Jersey (9), Illawarra Shorthorn (8), Australian Red (42), Brown Swiss cross (5), Holstein cross (3), Jersey cross (4), Australian Friesian Sahiwal (5), and unknown crossbreeds (10). Finally, samples from a total of 26 Brahman bulls were obtained. Of these, 3 were from a population described elsewhere (Barendse et al., 2009), and the remaining samples were from prepubescent to young adult bulls obtained from a research herd at CSIRO Livestock Industries (Armidale, Australia)

\section{Detection of Muc1 VNTR Polymorphisms}

The VNTR allelic polymorphisms in the Muc1 gene were detected by PCR using primers flanking the VNTR domain in exon 2 (sense primer $5^{\prime}$ CATAAACCCCCGCAGAACTA 3'; antisense primer 5' TAATATGGCTGGCAGCAGTG 3'; Figure 1). Polymerase chain reaction was undertaken with $1 \times$ PCR buffer, $200 \mu M$ deoxynucleotide $5^{\prime}$-triphosphates, $500 \mathrm{n} M$ each primer, 20 to $50 \mathrm{ng}$ of genomic DNA, and 0.6 U of HotStar Taq DNA polymerase (Qiagen) under the following conditions: denaturation at $94^{\circ} \mathrm{C}(15 \mathrm{~min})$, followed by 30 cycles of denaturation at $94^{\circ} \mathrm{C}(30 \mathrm{~s})$, annealing at $60^{\circ} \mathrm{C}(45 \mathrm{~s})$, and extension at $72^{\circ} \mathrm{C}(1.5 \mathrm{~min})$. The amplicons were separated on an agarose gel and visualized with ethidium bromide. A representation of each differently sized PCR product was excised, cloned into pGEM-T Easy vector (Promega, Sydney, Australia), and sequenced using BigDye Terminator v3.1 (Applied Biosystems, Melbourne, Australia). The current annotation of bovine Muc1 in the Btau_4.0 assembly in public databases incorrectly indicates that the gene has 9 exons. This error has arisen from discrepancies between cDNA and genomic sequences caused by VNTR variation of the alleles that were sequenced. Gene symbols are in italics when used in the context of the gene or mRNA and in normal font when referring to a protein. Human gene symbols are in capitals.

\section{Association of Muc1 VNTR Polymorphisms with Dairy Production Traits}

Holstein-Friesian sires (157, from Genetics Australia) with extensive EBV data were used for analysis of the association of Muc1 VNTR alleles with dairy production traits. The animals represented high and low extremes of the EBV for SCC; consequently, the statistical model used for trait association analysis required incorporation of a term to account for the introduced bias. A linear mixed model was used to test for association between Muc1 genotype and the EBV for the Australian profit ranking, a composite trait defined by the Australian Dairy Herd Improvement Scheme that includes milk production, milking speed, temperament, survival, SCC, and live weight; the Australian selection index, which accounts for production costs and the value of milk components and is weighted for the EBV protein, fat, and milk; protein $(\mathrm{kg})$; protein percentage; total milk yield $(\mathrm{L})$; fat $(\mathrm{kg})$; fat percentage; and SCC. The model was the following:

$$
\begin{gathered}
y=\text { mean }+ \text { HLSCC }+\beta_{1} \text { Allele }_{1}+\beta_{2} \text { Allele }_{2} \\
+ \text { Sire }+\varepsilon,
\end{gathered}
$$

where $y$ is the EBV for the trait; HLSCC is the effect of the high versus low SCC tail; Allele $_{1}$ is the number of copies of allele $1(0,1,2)$; Allele $_{2}$ is the number of copies of allele $2(0,1,2)$; Sire is the random effect for sire; $\beta_{1}$ and $\beta_{2}$ are the average effects on the trait for each additional copy of allele 1 and allele 2, respectively; and $\varepsilon$ is the random error. Only alleles D, E, and G were present in the tested population. The third allele was not included in the model because it is colinear with the first 2 alleles $\left(\right.$ Allele $_{1}+$ Allele $_{2}+$ Allele $\left._{3}=2\right)$. The term HLSCC was added to each model (other than 
the SCC trait model) to assess whether extreme tail selection for SCC may have been associated with the trait of interest, and hence may have biased estimates of any association. When found to be nonsignificant, this term was not used in the model. Assessment of the significance of fixed effects was conducted using Wald chi-square $\left(\chi^{2}\right)$ tests. For assessing the significance of the association between the various phenotypes listed above and the Muc1 alleles, the Wald test examined whether $\beta_{1}=\beta_{2}=0$ (2 df), and for HLSCC, the Wald test tested whether the single effect (high vs. low tail) was zero (1 df). The model fitting was implemented using REML procedures in GenStat Release 9 (Payne et al., 2005).

\section{Isolation of RNA and Quantitative Real-Time Reverse Transcription PCR}

Total RNA was extracted from bovine MEC grown in cell culture and processed to produce cDNA (Vuocolo et al., 2003). Quantitative real-time reverse transcription PCR (qRT-PCR) using the Sybr Green-based fluorescence detection system and the ABI Prism 7900 Sequence Detection System (Applied Biosystems, Melbourne, Australia) was used to measure mRNA expressed in mammary epithelial cells. The Muc1 sense primer was 5' GAGTGGGTGAAGGCACAGTT $3^{\prime}$ and the antisense primer was $5^{\prime}$ CAGAACACAGACCAGGAC $3{ }^{\prime}$. Data were analyzed using the Relative Expression Software Tool, which generates a mean normalized expression value of a target transcript relative to a reference gene (Pfaffl et al., 2002). Ten nanograms of reverse-transcribed RNA was used for each qRT-PCR measurement. Four technical replicates and 2 biological replicates were used for each gene. This process allowed quantification of the target gene relative to a constant reference gene in each sample by using threshold cycle data. Three potential reference genes, $18 \mathrm{~S}$ ribosomal RNA (GenBank accession no. DQ222453), glyceraldehyde 3-phosphate dehydrogenase (GenBank accession no. XM_868165), and ribosomal protein, large, P0 (RPLP0; GenBank accession no. BT021080), were independently assessed. The expression pattern of $R P L P 0$ showed the least variation; therefore, it was used as the reference gene. The RPLPO sense primer was $5^{\prime}$ CAACCCTGAAGTGCTTGACAT $3^{\prime}$ and the antisense primer was $5^{\prime}$ AGGCAGATGGATCAGCCA $3^{\prime}$.

Each qRT-PCR (5 $\mu \mathrm{L}$ total volume) contained 2.5 $\mu \mathrm{L}$ of $2 \times$ Sybr Green Master Mix (Applied Biosystems; $0.25 \mu \mathrm{L}$ of each primer, giving a final concentration of $450 \mathrm{n} M$ each; $1.0 \mu \mathrm{L}$ water; and $1.0 \mu \mathrm{L}$ of a 1:10 dilution of the stock cDNA template. The reaction included an initial denaturation at $95^{\circ} \mathrm{C}(10 \mathrm{~min})$, followed by 40 cycles of $95^{\circ} \mathrm{C}(15 \mathrm{~s})$ and $60^{\circ} \mathrm{C}(1 \mathrm{~min})$. All melt curves showed single peaks consistent with the presence of single amplicons. Each qRT-PCR assay was validated by amplicon size and sequence to authenticate the targeted gene. Amplification efficiency was measured for each amplicon and used in conjunction with the Relative Expression Software Tool gene quantification software (Pfaffl et al., 2002).

\section{Isolation of MFGM}

Full-cream milk (80 L, Holstein-Friesian animals, representing Muc1 alleles D, E, and G) was centrifuged at $2,000 \times g(15 \mathrm{~min})$ at room temperature $(\mathbf{R T})$. The cream fraction $(3.2 \mathrm{~L})$ was isolated and washed $(\times 3)$ in Tris-buffered saline (TBS; $50 \mathrm{~m} M$ Tris, $\mathrm{pH}$ 7.5, $150 \mathrm{~m} M$ $\mathrm{NaCl}$ ) containing $1 \mathrm{~m} M$ EDTA and $1 \mathrm{~m} M$ benzamidine, and centrifuged $(2,000 \times g, 15 \mathrm{~min}, \mathrm{RT})$ after each wash. The cream was resuspended in an equal volume of the buffer and homogenized until it coagulated into butter (approximately $10 \mathrm{~min}, 4^{\circ} \mathrm{C}$ ). The buttermilk was collected by filtration through cheesecloth and centrifuged $\left(100,000 \times g, 1 \mathrm{~h}, 4^{\circ} \mathrm{C}\right)$. The MFGM pellet was washed in PBS, recentrifuged, and stored at $-80^{\circ} \mathrm{C}$.

\section{Purification of Muc1 Released from MFGM}

The MFGM was resuspended in $100 \mathrm{~m} M$ Tris, $\mathrm{pH}$ 8.0, containing $0.4 \mathrm{mg} / \mathrm{mL}$ of trypsin (Promega, Sydney, Australia; 1:20 trypsin to protein) and incubated for 4 $\mathrm{h}$ at $37^{\circ} \mathrm{C}$. The solution was centrifuged $(100,000 \times g$, $30 \mathrm{~min}, 4^{\circ} \mathrm{C}$ ) and the supernatant was dialyzed against $20 \mathrm{~m} M$ Tris- $\mathrm{HCl}, \mathrm{pH}$ 7.0, containing $1 \mathrm{~m} M$ benzamidine hydrochloride and $1 \mathrm{~m} M$ EDTA. This procedure released the extracellular domain of Muc1 from MFGM by exploiting its resistance to tryptic digestion. The sample was then fractionated in the same buffer on a 10-mL DEAE Sepharose column (Amersham Biosciences, Rydalmere, Australia). Muc1 eluted as a broad peak between 200 and $400 \mathrm{mM} \mathrm{NaCl}$. These fractions were pooled, concentrated, and dialyzed against $50 \mathrm{mM}$ sodium phosphate, $\mathrm{pH}$ 7.0, containing $0.8 \mathrm{M}$ ammonium sulfate and then applied to a 10-mL Phenyl-Sepharose column (Amersham Biosciences). Muc1 eluted in the break-through fraction and was 90 to $95 \%$ pure, as measured by a combination of silver and Alcian Bluestained SDS-PAGE gels.

\section{SDS-PAGE Analysis}

Protein samples representing MFGM and purified bovine Muc1 were analyzed by SDS-PAGE under reducing conditions on 6 to $18 \%$ gradient gels. Proteins 
were stained with Coomassie Blue R250, silver, periodic acid-Schiff reagent, or Alcian Blue.

\section{Biotinylated Lectin Blots}

Purified Muc1 (5 $\mu \mathrm{g})$ was spotted onto a nitrocellulose membranes (Hybond-C, Amersham Biosciences), air-dried, washed in TBS containing $0.05 \%$ Tween 20 (TBS-T), and blocked with $2 \%$ BSA in TBS-T (30 min, RT). The membranes were incubated with biotinylated lectins (Vector Laboratories, Abacus ALS, Brisbane, Australia) at recommended concentrations (5 to $20 \mu \mathrm{g} / \mathrm{mL}$ ) in TBS-T (RT, $2 \mathrm{~h}$ ), washed in TBS-T $(3 \times 10 \mathrm{~min})$, incubated with streptavidin-biotinylated horseradish peroxidase complex (1:1,000 dilution; GE Healthcare, Rydalmere, Australia; RT, 2 h), and then washed in TBS-T $(3 \times 10 \mathrm{~min})$ and TBS $(2 \times 5 \mathrm{~min})$. Bound horseradish peroxidase-streptavidin complex was visualized on ECL Hyperfilm (Amersham Biosciences) by chemiluminescence after incubation of the membrane for $1 \mathrm{~min}$ in $0.04 \%$ luminol, $0.01 \%$ 4-iodophenyl, and $0.075 \%$ hydrogen peroxide in TBS. Binding was visually interpreted.

\section{Amino-Terminal AA Sequencing}

To determine the N-terminal AA sequences of proteins present in the MFGM and purified Muc1, proteins were separated by SDS-PAGE and transferred onto a polyvinylidene fluoride membrane (ProBlott, Applied Biosystems). Selected protein bands were sequenced using a 494 HT Procise Sequencer according to a standard protocol (Applied Biosystems).

\section{Peptide Sequencing}

Purified Muc1 was dialyzed into $8 M$ urea and $0.4 M$ ammonium bicarbonate, reduced (4 $\mathrm{m} M$ dithiothreitol, $\left.15 \mathrm{~min}, 50^{\circ} \mathrm{C}\right)$, and alkylated $(8 \mathrm{~m} M$ iodoacetamide, $15 \mathrm{~min}, \mathrm{RT}$ ). The sample was diluted in water to final concentrations of $2 M$ urea, $0.1 M$ ammonium bicarbonate, $1 \mathrm{~m} M$ dithiothreitol, $2 \mathrm{~m} M$ iodoacetamide, and sequencing-grade modified trypsin was added to a final enzyme-to-protein ratio of 1:20. The reaction mixture was incubated for $24 \mathrm{~h}$ at $37^{\circ} \mathrm{C}$, and the resulting peptide fragments were analyzed by matrix-assisted laser desorption/ionization-time of flight/time of flight mass spectrometry on a 4700 Proteomics Analyzer according to a standard protocol (Applied Biosystems). Mass spectra were recorded in positive reflector mode at a laser intensity of 4,800. Tandem mass spectrometry (MS/MS) data were acquired using the default MS/MS method (positive ion, 1-kV collision energy, reflectron mode, laser intensity of 5,500). Data were processed using GPS Explorer software, Version 3.5 (Applied Biosystems), which incorporated the Mascot peptide mass fingerprinting and MS/MS ion search software (Version 1.9.05, Matrix Science, London, UK) in conjunction with publicly available bovine protein sequence information.

\section{AA and Monosaccharide Compositional Analyses}

Two independent MFGM preparations, as described above, were used to purify Muc1 samples for AA and monosaccharide analyses. Amino acid analysis was carried out by the Australian Proteome Analysis Facility (Sydney, Australia) using standard protocols. Cysteine and Trp contents were not determined. Data are presented as the mean of 2 independent analyses. Monosaccharide composition analysis was performed by the Glycotechnology Core Resource (University of California, San Diego, CA) using standard protocols. The relative amounts of monosaccharides on Muc1 are presented as mole percentage of the total monosaccharide content (mean of 2 independent analyses). Muc1 was also incubated with Clostridium perfringens neuraminidase (Roche Diagnostics, Castle Hill, Australia; $1 \mathrm{mU} / \mu \mathrm{g}$ of glycoprotein) in $50 \mathrm{~m} M$ sodium acetate buffer, pH 5.0, containing $150 \mathrm{mM} \mathrm{NaCl}\left(37^{\circ} \mathrm{C}, 24 \mathrm{~h}\right)$. Changes in mobility and characteristic staining patterns of Muc1 on SDS-PAGE were monitored, and monosaccharide compositional analysis of a single sample was performed to demonstrate the removal of neuraminic acid (sialic acid; Neu).

\section{Bacterial Culture}

A nonpathogenic strain of E. coli (O-, H48) was grown in brain heart infusion (BHI, Oxoid, Adelaide, Australia) medium. Brain heart infusion broth was inoculated with a single bacterial colony-forming unit taken from a BHI agar plate and incubated overnight at $37^{\circ} \mathrm{C}$ under anaerobic conditions. A log phase culture was prepared by inoculating $10 \mathrm{~mL}$ of $\mathrm{BHI}$ broth with a $1 \times 10^{9} \mathrm{cfu}$ aliquot of the overnight culture, followed by further incubation for $3 \mathrm{~h}$.

\section{Direct Binding of E. coli to Immobilized Muc1}

Muc1 was serially diluted (loadings: 0.1 to $100 \mu \mathrm{g}$ ) and adsorbed onto a Whatman Westran S polyvinylidene fluoride membrane (Sigma-Aldrich, Castle Hill, Australia) using a Bio-Dot SF microfiltration apparatus (Bio-Rad, Gladesville, Australia). The membrane was blocked with PBS containing 5\% BSA (1 h, RT). Labeling of bacteria with NHS-LC-Biotin (Pierce, Quantum Scientific, Murarrie, Australia) was performed following 
the instructions of the manufacturer for labeling cell surface proteins. Excess probe was removed (3 washes in $1 \mathrm{~mL}$ of PBS containing $100 \mathrm{mM}$ Gly) and the cell pellet was resuspended in $40 \mathrm{~mL}$ of PBS containing $5 \%$ BSA. An aliquot of this suspension was overlaid onto the membrane $\left(0.3 \mathrm{~mL} / \mathrm{cm}^{2}\right)$ and incubated overnight $\left(4^{\circ} \mathrm{C}\right)$. The membrane was washed $(3 \times 5 \mathrm{~min}$; PBS containing $0.1 \%$ Tween-20) and adherent bacteria were detected using horseradish peroxidase-conjugated streptavidin complex and standard chemiluminescence techniques (Pierce, Quantum Scientific). Images for densitometric quantification of bacterial binding were captured on a Kodak 440CF imaging station and analyzed using Kodak 1D imaging software (Eastman Kodak Company, Rochester, NY). The assay was independently performed twice with each Muc1 dilution analyzed in triplicate. The difference between the binding to Muc1 and the BSA control at each protein concentration was determined and then expressed as a percentage of the maximal binding. The percentage of specific binding is presented as the mean \pm standard error of the mean.

\section{Binding of Fluorescently Labeled E. coli BioParticles to MFGM}

Equal volumes of fluorescein-conjugated E. coli (K-12 strain) BioParticles (Invitrogen, Mount Waverley, Australia; $1 \mathrm{mg} / \mathrm{mL}$ ) and $500 \mu \mathrm{g} / \mathrm{mL}$ of MFGM were mixed and incubated in PBS for $1 \mathrm{~h}$ at RT. The BioParticles were visualized using an Axiophot fluorescence microscope (Carl Zeiss Pty. Ltd., North Ryde, Australia).

\section{Culture of Bovine MEC}

The isolation, culture, and characterization of primary MEC have been described previously (Strandberg et al., 2005). Bovine MEC were seeded at $4 \times 10^{4}$ cells per well in a 6 -well plate coated with collagen type I from calf skin (Sigma-Aldrich) and cultured until 80\% confluent. They were then washed in PBS before addition of fresh media with or without LPS (E. coli strain 055:B5, Sigma-Aldrich) or lipoteichoic acid (LTA; Staphylococcus aureus; Sigma-Aldrich) at final concentrations of 50 and $20 \mu \mathrm{g} / \mathrm{mL}$, respectively. After incubation for 0,2 , $4,8,16$, and $24 \mathrm{~h}$, the cells were washed with PBS before harvesting for subsequent RNA extraction. For the LPS dose-response study, bovine MEC were stimulated with LPS (0.01 to $50 \mu \mathrm{g} / \mathrm{mL})$ for $24 \mathrm{~h}$.

\section{Binding of Bacteria to Bovine MEC}

The effect of Muc1 on the binding of the fluoresceinconjugated E. coli (K-12 strain) BioParticles to MEC was measured as follows. Bovine MEC $\left(1 \times 10^{5}\right.$ cells/ well) were cultured in a collagen type 1 (calf skin)-coated black 96-well plate (Greiner Bio-One GmbH, Frickenhausen, Germany) overnight $\left(37^{\circ} \mathrm{C}\right)$. The BioParticles $(1 \mathrm{mg} / \mathrm{mL})$ were added to MFGM $(500 \mu \mathrm{g} / \mathrm{mL})$ at $20^{\circ} \mathrm{C}$ with agitation for $2 \mathrm{~h}$, before addition of $100 \mu \mathrm{L}$ of the mixture to the MEC (in triplicate). After further incubation $\left(2 \mathrm{~h}, 37^{\circ} \mathrm{C}\right)$, the cells were washed $(\times 2)$ with PBS and residual cell-bound florescence (emission 480 $\mathrm{nm}$, excitation $520 \mathrm{~nm}$ ) measured on a Polarstar fluorometer (BMG Labtech Pty. Ltd., Mornington, Australia). Bovine serum albumin was used as the control.

\section{Statistical Analysis}

In addition to the statistical methods outlined for the detection of Muc1-trait associations, data on other measures (E. coli binding, Muc1 expression fold changes) are presented in the text and figures as the mean \pm standard error of the mean. Significance for these measures was ascertained using ANOVA. $P$-values $\leq 0.05$ were considered significant.

\section{RESULTS}

\section{Bovine Muc1 VNTR Gene Polymorphisms}

The cytoplasmic and transmembrane domains in Muc1 are relatively conserved in mammals (e.g., 76 and 93\% AA identities between human and bovine Muc1, respectively). However, the bovine VNTR domain shows an atypically low level of conservation (e.g., $41 \%$ between human and bovine Muc1). The genomic organization of the bovine $M u c 1$ gene is shown in Figure 1, which also highlights the position of primers used to amplify exon 2. A total of 630 cattle were surveyed to assess the extent of VNTR polymorphism in exon 2 of the Muc1 gene. Nine principal VNTR allelic variants were identified from individuals representing 15 genotypes. Figure 2 shows PCR products derived from representative individuals of the different genotypes, with each allele assigned a letter A to I. The DNA sequencing demonstrated a fundamental VNTR unit structure of $60 \mathrm{bp}$ (encoding $20 \mathrm{AA}$ ), although there were 4 different major VNTR units, with encoded AA sequence identities between 65 and $80 \%$ (mean $75 \%$; Figure $2 \mathrm{~b}$ ). There were also additional minor sequence variations to 3 of the 4 major VNTR units. All the VNTR units were characterized by absolute identity of 9 of the first 10 AA but only 2 of the last 10 AA. In particular, 4 Pro residues in the first 10 AA of all VNTR units were absolutely conserved, suggesting that these may be important for an extended backbone structure of the repeat unit. The VNTR units contained 3 abso- 
(a)

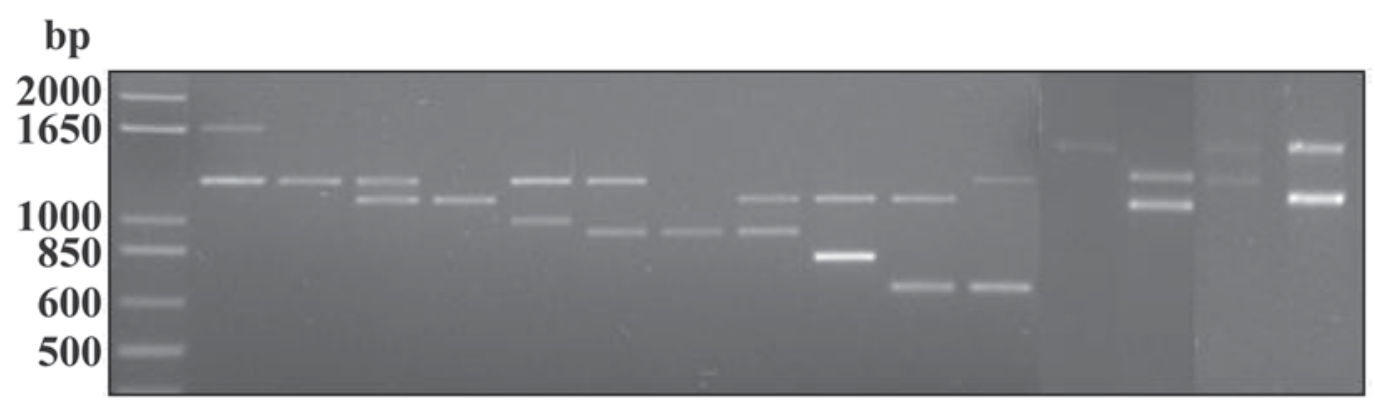

$S$ AD DD DE EE DF DG GG EG EH EI DI BB BD BE CE

(b)
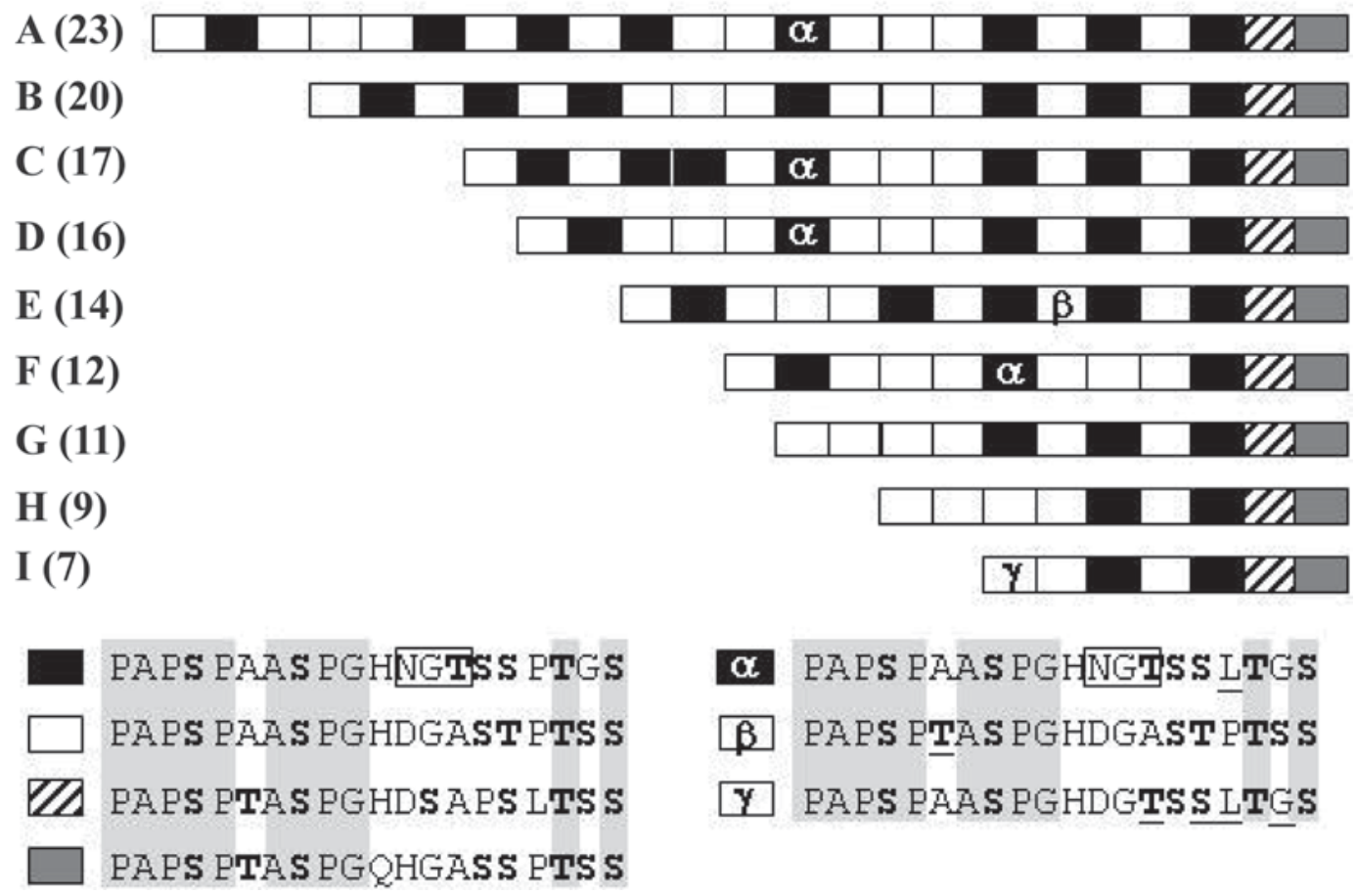

$\alpha$ PAPS PAAS PGHNGTS LTGS

$\beta$ PAPS PTAS PGHDGASTPTSS

Y PAPS PAAS PGHDGTSS LTGS

Figure 2. Analysis of bovine Muc1 variable number of tandem repeat (VNTR) allelic variants. (a) Amplified Muc1 PCR products from DNA samples representative of individual animals. The PCR primers were positioned to flank the VNTR region in exon 2 of Muc1. Individual alleles are represented by the letters A to I. S = size standards. The lanes are labeled according to genotype. (b) Organization of VNTR units and their AA sequences in bovine Muc1 allelic variants. Each allelic variant consists of a series of VNTR units, each of which is represented by a box. The letters A to I represent each allele and the number in brackets is the number of VNTR units. The 4 major types of VNTR units are represented as differently shaded boxes. Small variations within the major VNTR units are marked with different Greek symbols embedded in the shading of the major VNTR unit. The AA sequence of each VNTR unit is also shown, and residues that have $100 \%$ identity between the 4 major VNTR units are shaded gray. Potential O-linked glycosylation sites are marked in bold font and potential N-linked glycosylation consensus sites are boxed. The small differences in some VNTR unit sequences are underlined.

lutely conserved Ser and 1 absolutely conserved Thr, as well as several less conserved Ser and Thr residues, all of which are predicted to be involved in O-linked glycosylation (Figure 1c). One of the 4 major VNTR units contains an N-linked glycosylation site; therefore, the frequency and position of this VNTR unit in an allele could alter the glycosylation type on the encoded Muc1 protein.

The number of VNTR units varied between 7 and 23 in the 9 identified allelic variants. The longest allele (A, containing 23 VNTR units encoding 460 AA) corresponds to a predicted size (excluding glycosylation) 
Table 1. Bovine $M u c 1$ allele frequencies

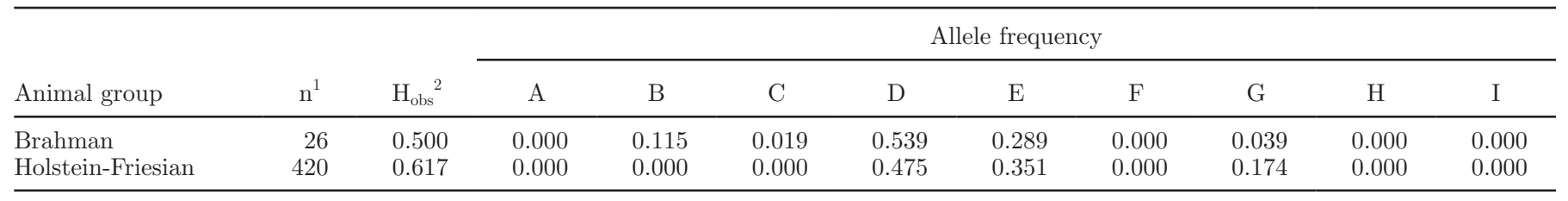

${ }^{1} \mathrm{n}=$ number of individuals.

${ }^{2} \mathrm{H}_{\mathrm{obs}}=$ observed heterozygosity value (GenePop WWW software; Raymond and Rousset, 1995).

of the mature Muc1 polypeptide of $78.7 \mathrm{kDa}$, whereas the shortest (I, 7 VNTR units, 140 AA) encodes a mature polypeptide of $50.4 \mathrm{kDa}$. Thus, the VNTR allelic variations can produce Muc1 proteins with considerable size differences; this is more accentuated if only the extracellular domains of the Muc1 allelic variants are considered. Bovine Muc1 contains a conserved sequence, $\mathrm{G}^{\wedge} \mathrm{SVVV}$, in the SEA domain that undergoes proteolytic cleavage in the human ortholog (Gendler, 2001). Therefore, the potential proteolytically released extracellular domain could vary markedly in size from 32.3 to $60.6 \mathrm{kDa}$ (excluding glycosylation) because of allelic variation. For all 9 alleles, the 4 most C-terminal VNTR units are each different but their relative order is absolutely conserved (Figure 2). Thus, allelic variation was generated at the N-terminal end of the VNTR region. Two VNTR units (the first 2 of the 4 most C-terminal VNTR units) are the most prevalent, together representing 71 to $91 \%$ of the VNTR units in the alleles.

The allele frequencies and observed heterozygosity values obtained using GenePop software (Raymond and Rousset, 1995) for the Muc1 gene in 2 cattle herds representing Brahman and Holstein-Friesian animals are shown in Table 1 . The predominant alleles were D (16 VNTR units), E (14 VNTR units), and G (11 VNTR units). The shorter (F, G, H, I) and longer (A, B, C) alleles were relatively rare or absent in this population. Alleles B (20 VNTR units) and C (17 VNTR units) were found only in Brahman animals.

\section{Associations of Muc1 VNTR Polymorphisms with Dairy Production Traits}

Linear mixed models were used to test for association between the alleles and dairy production traits. An explanatory variable, HLSCC (effect of the high vs. low SCC tail), was added to each model to assess whether extreme tail selection for SCC was associated with the trait of interest, and hence biased estimates of any association. Table 2 shows the association between each trait and Muc1 genotype. Notably, there was no association between the Muc1 genotype and SCC ( $P$ $=0.58)$, an indirect measure of mastitis susceptibility in dairy cattle, although SCC was significantly associ- ated with Australian profit ranking, total milk yield, and fat percentage. There was suggestive evidence of associations with protein $(P=0.062)$ and fat percentage $(P=0.080)$. However, there was also a significant association of fat percentage with HLSCC $(P=0.025)$. Because the SCC distribution involves the distribution tails only, then by association, the distribution of fat percentage EBV will be somewhat similarly affected. This may lead to a small overestimation of the degree of association.

\section{Purification of the Extracellular Domain of Bovine Muc1 from Milk}

Muc1 protein, representing a mixture of alleles D, $\mathrm{E}$, and G only, was purified from MFGM derived from the cream fraction of milk. Figure 3a shows an SDSPAGE profile of the proteins present in MFGM. The indicated proteins were identified by $\mathrm{N}$-terminal AA sequencing. Muc1 was characterized as a diffuse, poorly silver-stained band of size 120 to $180 \mathrm{kDa}$. One contributing factor to the diffuse nature of the Muc1 protein band may be the differently sized polymorphic variants present in the sample. The protein size was markedly larger than that predicted from the mature sequences of alleles D, E, and $\mathrm{G}(39,45$, and $48 \mathrm{kDa}$, respectively), which was probably due to anomalous electrophoretic behavior caused by substantial glycosylation.

The absence of Lys and Arg in the VNTR domain of Muc1 suggested that it would be largely trypsin resistant. Indeed, when MFGM was incubated with trypsin, a large trypsin-resistant protein showing poor staining properties on SDS-PAGE was released. This protein was purified by anion exchange and hydrophobic interaction chromatography (Figure 3b). Characteristically, after SDS-PAGE, the purified protein was not stained with Coomassie Blue and was only poorly stained with silver. The periodic acid-Schiff reagent selectively stained the protein, although it was stained most efficiently with Alcian Blue (Figure 3b). The latter is a blue cationic dye that stains acidic residues, particularly Neu containing oligosaccharides on mucins.

The identity of the purified protein as Muc1 was demonstrated by direct $\mathrm{N}$-terminal AA sequencing, 
(a)

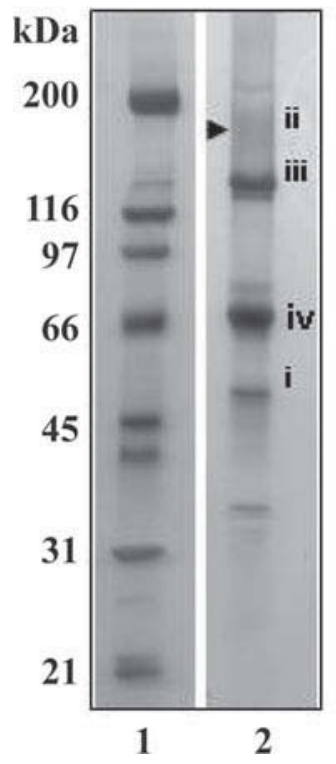

(b)

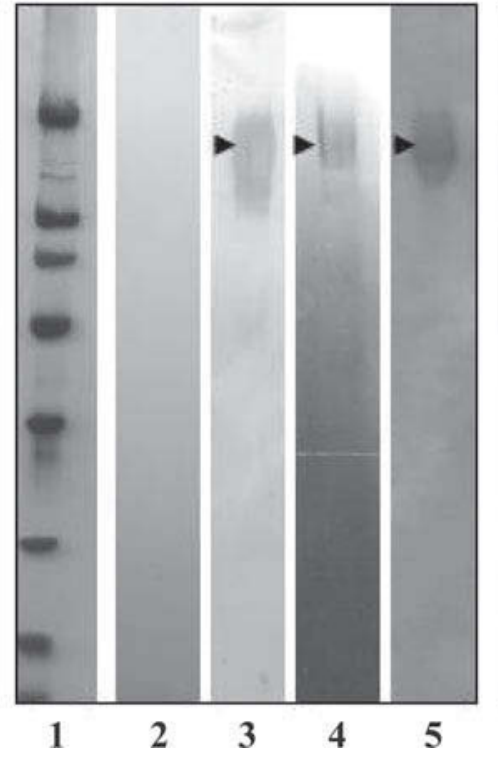

(c)

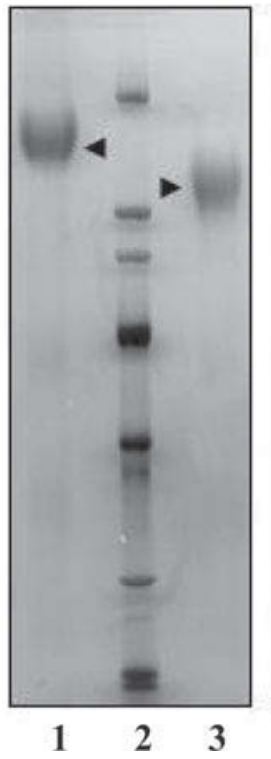

(d)

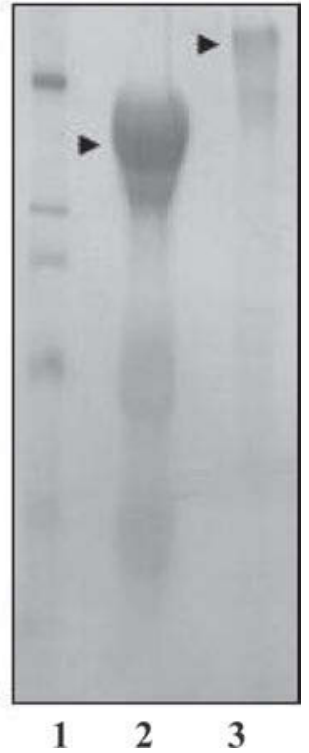

Figure 3. Sodium dodecyl sulfate-PAGE analysis of bovine Muc1. (a) Lane 1, protein size standards; lane 2, milk fat globule membrane (MFGM) proteins (N-terminal sequences): (i) butyrophilin (APFDVIGPXE); (ii) Muc1 (NVPTLTTSD); (iii) xanthine dehydrogenase (TADELVFFVNG); (iv) platelet glycoprotein IV (CD36; GCNRNCGLIA). (b) Lane 1, silver-stained protein size standards; lanes 2 to 5 , purified Muc1 stained with Coomassie Blue, silver, periodic acid-Schiff reagent, and Alcian Blue, respectively. (c) Lane 1, purified Muc1 allelic variant D [16 variable number of tandem repeat (VNTR) units]; lane 2, protein size standards; lane 3, purified Muc1 allelic variant G (11 VNTR units). (d) Lane 1, protein size standards; lanes 2 and 3, Muc1 pre- and postdesialylation, respectively, stained with silver and then counterstained with Alcian Blue. The arrowheads denote Muc1.

which revealed the sequence NVPTLTTSD. This sequence began at residue 23 immediately following the predicted signal sequence (European Molecular Biology Laboratory accession no. AJ400824; Figure 4). Two Muc1 peptides were also identified from the purified protein after additional in-solution tryptic digestion and detection of peptides by using matrix-assisted laser desorption/ionization-time of flight/time of flight mass spectrometry peptide sequencing. These peptides, VSLYFLSFR and SIWGLILQIYKQR, are located within the Muc1 SEA domain. Very few peptides were produced by the action of trypsin on the purified Muc1 released from MFGM. The lack of tryptic peptides from the cytoplasmic domain and the proteolytic release of the intact glycosylated extracellular domain indicate the absence of the transmembrane and cytoplasmic domains in the protein released from MFGM. There are only 3 tryptic cleavage sites between the end of the most C-terminally identified peptide and the transmembrane domain; thus, the C-terminus of the purified

Table 2. Significance of association of Muc1 genotype with dairy production traits

\begin{tabular}{lccccc}
\hline & \multicolumn{3}{c}{ Muc1 } & & \multicolumn{2}{c}{ HLSCC $^{2}$} \\
\cline { 2 - 3 } \cline { 5 - 5 } Trait $^{1}$ & $\chi^{2}(2 \mathrm{df})$ & $P$-value & & $\chi^{2}(1 \mathrm{df})$ & 9.96 \\
\hline APR & 0.27 & 0.874 & & 0.04 & 0.002 \\
ASI & 0.87 & 0.647 & & 2.17 & 0.842 \\
Prot & 0.63 & 0.730 & & 1.13 & 0.141 \\
Prot\% & 5.56 & $0.062^{3}$ & & 3.27 & 0.289 \\
Milk & 1.43 & 0.489 & & 0.55 & 0.070 \\
Fat & 1.75 & 0.417 & & 5.03 & 0.460 \\
Fat\% & 5.05 & $0.080^{3}$ & & - & - \\
SCC & 1.09 & 0.580 & & & \\
\hline
\end{tabular}

${ }^{1} \mathrm{APR}=$ Australian profit ranking; ASI = Australian selection index; Prot = milk protein $(\mathrm{kg}) ; \operatorname{Prot} \%=$ milk protein percentage; Milk $=$ total milk yield $(\mathrm{L}) ;$ Fat $=$ milk fat $(\mathrm{kg}) ;$ Fat $\%=$ milk fat percentage.

${ }^{2} \mathrm{HLSCC}=$ effect of high versus low SCC tail. HLSCC is an explanatory variable in the statistical model that explains the contribution arising from selection of the animals on the basis of high and low SCC.

${ }^{3}$ Suggestive significance after adjustment for the contribution of HLSCC. 
protein must reside within this 25-AA segment, which includes the consensus sequence (G^SVVV) associated with natural proteolytic processing of Muc1 in other species (Figure 4). Muc1 polymorphic protein variants were also independently isolated and purified from MFGM derived from cows that were homozygous for allelic variants D or G (Figure 3c). The size difference estimated by SDS-PAGE (approximately 20\%) for the 2 alleles agrees with the predicted value (18\%), assuming a putative C-terminus near the conserved natural proteolytic processing site ( $\left.\mathrm{G}^{\wedge} \mathrm{SVVV}\right)$.

\section{AA and Monosaccharide Compositions of Bovine Muc1 Released from MFGM}

The Muc1 samples used for compositional analyses were sourced from milk derived from Holstein-Friesian cows represented only by alleles D, E, or G. The AA composition is consistent with a typical mucin, with high abundance of Ser (30.1\%), Pro (17.5\%), Thr $(13.9 \%)$, Ala $(13.4 \%)$, and Gly $(8.2 \%)$ residues (Figure $4 \mathrm{~b})$. These collectively account for $83.1 \%$ of the AA and emphasize the predominant contribution of the VNTR domain to the AA composition (Figure 2). The prevalence of Ser and Thr, particularly in the VNTR region, underlies the potential for extensive O-linked glycosylation on Muc1 (Figure 1). Figure 4c shows that the major monosaccharides detected on purified Muc1 were Neu, galactose $(\mathbf{G a l})$, and N-acetylgalactosamine (GalNAc; 34.4, 33.3, and $19.7 \mathrm{~mol} \mathrm{\% ,} \mathrm{respectively),}$ and these collectively accounted for $87.4 \%$ of the total monosaccharide content. This suggests a high prevalence of O-linked sialyl-T-antigen [i.e., Neu5Ac( $\alpha 2-3)$ Gal( $\beta 1-3)$-GalNAco1] bound to Ser and Thr residues (Burchell et al., 2001). The relative abundance of $\mathrm{Neu}$ is also consistent with the unusual staining properties of Muc1 subjected to SDS-PAGE. Present in substantially lower quantities were $\mathrm{N}$-acetylglucosamine and mannose (5.2 and $7.1 \mathrm{~mol} \%$, respectively), and lesser extents of glucose and fucose (both $<1 \mathrm{~mol} \%$ ), which are generally characteristic of N-linked oligosaccharides (Lakhtin, 1995). Muc1 has 3 predicted N-linked glycosylation sites outside its VNTR region, and 1 of the more prevalent VNTR units also has a potential Nlinked site. It is estimated that Muc1 contains approximately $60 \%$ (wt/wt) carbohydrate. The abundance of Neu on bovine Muc1 was underscored by its reduced mobility, less diffuse band, and loss of Acian Blue staining in SDS-PAGE after treatment with C. perfringens neuraminidase (Figure 3d). Monosaccharide compositional analysis of Muc1 after neuraminidase treatment showed that greater than $95 \%$ of Neu was efficiently removed (result not shown).

\section{Binding of Biotinylated Lectins to Muc1 Released from MFGM}

Muc1 was screened for binding by 18 biotinylated lectins by using immunoblots to provide information on its oligosaccharide structures (Table 3). Muc1 reacted with peanut lectin (PNA) but only after desialylation with neuraminidase, and with Jacalin lectin before and after desialylation. Both PNA and Jacalin have high affinities for T-antigen $[\mathrm{Gal}(\beta 1-3)$-GalNAco1; Lakhtin, 1995]. However, unlike PNA, Jacalin also binds this structure when Gal is substituted with an additional monosaccharide, such as Neu (Tachibana et al., 2006). Evidence for Neu substitution at the C-3 position of Gal was obtained from the positive reaction of Muc1 with Maackia amurensis lectin II (hemagglutinin), which binds Neu in an $\alpha 2-3$ linkage. This reactivity was lost upon neuraminidase treatment. Muc1 reacted only weakly with Sambucus nigra lectin, which preferentially binds a2-6-linked Neu (Lakhtin, 1995). Collectively, these lectin-binding properties demonstrated the presence of O-linked sialyl-T-antigen, as suggested from the monosaccharide compositional analysis. The latter analysis also implied the presence of some N-linked glycans, and this was supported by reactivity of desialylated Muc1 with concanavalin A, which preferentially binds N-linked oligosaccharides with terminal $\alpha$-linked mannose structures (Lakhtin, 1995).

\section{Muc1 Sequesters E. coli and Inhibits E. coli Binding to Bovine MEC Grown In Vitro}

Figure 5a shows that fluorescein-conjugated E. coli BioParticles were bound by MFGM. Purified Muc1 was assessed for its ability to interact directly with bacteria by quantifying the level of biotinylated $E$. coli specifically adhering to purified bovine Muc1 immobilized on a membrane. Figure 5b demonstrates that biotinylated E. coli binds Muc1 in a dose-dependent manner. Next, it was investigated whether the binding of Muc1 to $E$. coli could inhibit the interaction of $E$. coli with bovine MEC grown in vitro. The adherence of fluoresceinconjugated E. coli BioParticles to the surface of MEC was measured with and without preincubation of the BioParticles with Muc1. Preincubation of the BioParticles with Muc1 significantly $(P=0.033)$ reduced their adherence to MEC by $66.7 \pm 5.3 \%$ (Figure $5 \mathrm{c}$ ).

\section{Muc1 mRNA Expression in Bovine MEC Stimulated with LPS or LTA}

The binding of Muc1 to E. coli suggested that it was involved in innate immune defense. Consequently, 
the expression of $M u c 1$ was investigated to determine whether it was responsive to immune stimuli, as are many innate immune genes. Muc1 mRNA was measured by qRT-PCR in bovine MEC challenged in vitro with the gram-negative or gram-positive bacterial cell wall components LPS or LTA, respectively (Figure 6). After $24 \mathrm{~h}$ of stimulation, Muc1 mRNA was significantly increased $(2.21 \pm 0.02$-fold; $P<0.05)$ even at the lowest concentration of LPS tested $(0.01 \mu \mathrm{g} / \mathrm{mL})$ and increased in a dose-dependent manner until, at $50 \mu \mathrm{g} /$ $\mathrm{mL}$ of LPS, there was an $8.2 \pm 0.1$-fold increase $(P<$ 0.001; Figure 6a). Muc1 expression increased within $8 \mathrm{~h}$ of the MEC being stimulated with $50 \mu \mathrm{g} / \mathrm{mL}$ of LPS ( $P$ $<0.001$ ) and increased further over time (Figure $6 \mathrm{~b}$ ). A similar response was not observed in MEC stimulated with LTA, because Muc1 expression levels increased only slightly in response to $20 \mu \mathrm{g} / \mathrm{mL}$ of LTA $(1.92$ \pm 0.01 -fold increase by $24 \mathrm{~h} ; P=0.007)$. Thus, the

(a)

MTPDIQAPFLSLLLLFPVLTVANVPTLTTSDSINPRRTTPVSTTQSSPTSSPTKETSWSTTTTLLTASS PAPSPAASPGHDGASTPTSSPAPSPAASPGHDGASTPTSSPAPSPAASPGHDGASTPTSSPAPSPAAS

PGHDGASTPTSSPAPSPAASPGHNGTSSPTGSPAPSPAASPGHDGASTPTSSPAPSPAASPGHNGTSS

PTGSPAPSPAASPGHDGASTPTSSPAPSPAASPGHNGTSSPTGSPAPSPTASPGHDSAPSLTSSPAPSP

TASPGQHGASSPTSSDTSSMTTRSMSSSMVTSAHKGTSSRATMTPVSKGTPSSVPSSETAPTAASHI

TRTAASSPSIALSTSSNPKTSQQLSVR VSLYFLSFRITNLQF NSSLENPQTSYYQELQRSIWGLILQIYKQR DFLGLSEIKFRPGSVVVELTLAFREGTTAEWVKAQFSQLEAHAASY $\underline{\mathbf{N}} L T I S G V S V Y S A P F P S S A Q A G S G$ VPGWGIALLVLVCVLVALAIIYLIALVVCQCGRKKCEQLDVFPTLDAYHPMSEYSTYHTHGRYVP PGSTKRSPYEEVSAGNGGSNLSYTNLAATSANL

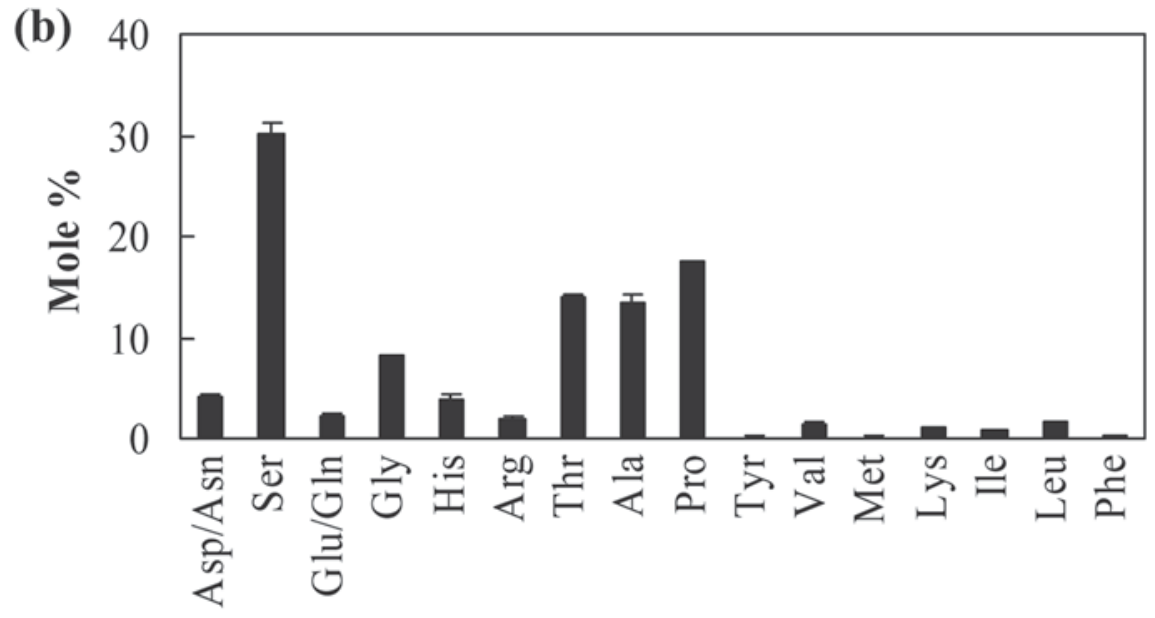

Amino Acid

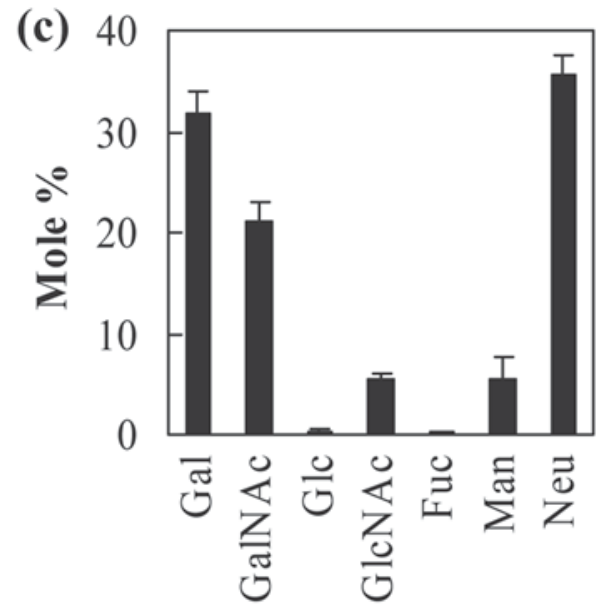

Monosaccharide

Figure 4. Predicted sequence, AA composition, and monosaccharide composition of bovine Muc1. (a) Predicted AA sequence of bovine Muc1 deduced from publicly available mRNA sequence (European Molecular Biology Laboratory Database, accession no. AJ400824, representing allelic variant G). The signal peptide cleavage site is marked with an open arrow; the N-terminal sequence confirmed by direct sequencing is underlined; each of the variable number of tandem repeat (VNTR) units is boxed; the SEA (initially identified in sperm protein, enterokinase, and agrin) module is shown in italic font; tryptic peptide sequences identified by mass spectrometry are underlined; the proposed endogenous proteolytic cleavage site is marked with a closed arrow; the transmembrane domain is underlined twice; and Asn residues in the consensus sequence for N-linked glycosylation are bolded. (b) AA composition of purified bovine Muc1 released from milk fat globule membrane (MFGM). The results show the mean of 2 independent determinations. (c) Monosaccharide composition of purified bovine Muc1 released from MFGM. The results show the mean of 2 independent determinations. Gal $=$ galactose; GalNAc $=N$-acetyl-galactose; Glc $=$ glucose; GlcNAc $=N$-acetylglucosamine; Fuc = fucose; Man = mannose; Neu = neuraminic acid (sialic acid). 
Table 3. Binding of biotinylated lectins to bovine Muc1 released from milk fat globule membrane

\begin{tabular}{|c|c|c|c|}
\hline Biotinylated lectin & Specificity $^{1}$ : major (lesser) & Muc1 & Muc1- $\mathrm{n}^{2}$ \\
\hline Dolichos biflorus agglutinin & $\alpha$-GalNAc & - & - \\
\hline Lens culinaris agglutinin & $\alpha$-Man, chitobioseNAc- $\alpha$-Fuc & - & - \\
\hline Maackia amurensis lectin I & $\mathrm{Neu}(\alpha 2-3)-\mathrm{Gal}(\beta 1-4)-\mathrm{GlcNAc}$ & - & - \\
\hline M. amurensis lectin II & $\mathrm{Neu}(\alpha 2-3)$ & + & - \\
\hline P. vulgaris leucoagglutinin & Lymphocytes & - & - \\
\hline Pisum sativum agglutinin & $\alpha$-Man, chitobioseNAc- $\alpha$-Fuc & - & + \\
\hline Ricinus communis agglutinin I & $\beta / \alpha$-Gal, $\alpha$-GalNAc & - & + \\
\hline Sambucus nigra lectin & $\operatorname{Neu}(\alpha 2-6),[\mathrm{Neu}(\alpha 2-3)]$ & + & - \\
\hline Sophora japonica agglutinin & $\alpha$-GalNAc, $\alpha$-Gal & - & - \\
\hline Soybean agglutinin & $\alpha / \beta$-GalNAc, $[\alpha / \beta$-Gal $]$ & - & - \\
\hline Succinylated wheat germ agglutinin (WGA) & GlcNAc & - & - \\
\hline
\end{tabular}

expression of Muc1 mRNA was markedly stimulated by the presence of LPS but was much less affected by LTA.

\section{DISCUSSION}

There have been few detailed investigations of the structure and functions of bovine Muc1, despite speculations that it may have important roles in the physical properties of milk and have an antimicrobial protective role. Comparison of the VNTR polymorphisms in mammalian species indicates that the most polymorphic Muc1 genes occur in species with high levels of sequence conservation between the individual VNTR units. For example, human $M U C 1$ is the most polymorphic ( $>30$ alleles) and has the highest VNTR unit sequence conservation (97 to $100 \%$ identity), followed by caprine, bovine, ovine, and finally murine, which does not exhibit any polymorphism and has the lowest VNTR sequence conservation (Spicer et al., 1991; Gendler, 2001; Rasero et al., 2002; Sacchi et al., 2004; Rasero et al., 2007). This mirrors the general association between polymorphism potential and sequence homogeneity in minisatellites (Jarman and Wells, 1989). The Muc1 VNTR region can be considered as an expressed coding sequence minisatellite (Patton et al., 1995); thus, the formation of allelic variants probably occurs by mispairing of DNA tandem repeats, followed by unequal sister-chromatid exchange (Sacchi et al., 2004). Mutations involving gain or loss of VNTR units in minisatellites typically occur at the $5^{\prime}$ end of tandem repeats, as for Muc1 (Jeffreys et al., 1994). Thus, the more polymorphic genes contain the greatest conservation of the repeat sequence. The murine Muc1 gene may have undergone an unequal exchange event in the past, leading to reduced VNTR unit homology and consequent loss of potential for VNTR polymorphism (Spicer et al., 1991).

The substantial VNTR allelic variation in bovine Muc1 may underlie functional differences in the protein. There was suggestive evidence for an association of the Muc1 variants with the milk production traits protein percentage and fat percentage, although further research is required to validate these associations and to rule out the possibility of a more distantly placed polymorphism in linkage disequilibrium with specific Muc1 VNTR alleles.

Muc1 allelic variants of very different sizes and with consequential glycosylation differences may play a physical role in dictating the size of the milk fat globules. This, in turn, could affect the triglyceride-carrying capacity of milk and hence lead to an association between Muc1 alleles and the fat content of milk. Further, measurement of $\beta-\mathrm{CN}$ and $\alpha_{\mathrm{s} 1}-\mathrm{CN}$ mRNA in bovine mammary tissue showed highly significant correlations with Muc1 mRNA (data not shown), thereby potentially supporting a relationship between the Muc1 alleles and milk protein content. There was no association between Muc1 alleles and SCC, which is a measure of susceptibility to mastitis in dairy cattle, even though Muc1 binds E. coli. One possibility is that the bacterial-binding capacities of the allelic variants are equivalent despite their considerable structural differences. The abilities of the D and $\mathrm{G}$ alleles to prevent adherence of bacteria 
to cells grown in culture were also compared. Although there was no significant difference, there was a trend for the longer allele to be more efficacious (result not shown). These 2 alleles may not be sufficiently different to highlight functional differences. It is noteworthy that human MUC1 shows an association between VNTR allele size and susceptibility to gastritis (Vinall et al., 2002), and a variety of human mucins have shown associations between their VNTR alleles and disease susceptibility (Thornton et al., 2008). Thus, functional differences among the bovine Muc1 allelic variants are anticipated. The binding of bacteria by Muc1 may help prevent mammary tissue infections (mastitis) and reflect an early biological response to infection, which is not associated with changes in neutrophil populations (i.e., SCC).

The functions of Muc1 in milk are probably closely associated with its major architectural feature, extensive glycosylation. Bovine Muc1 is heavily glycosylated, primarily with simple sialylated O-linked oligosaccharides, reflecting a predominance of O-linked sialylT-antigen oligosaccharide. A similar conclusion was

(a)
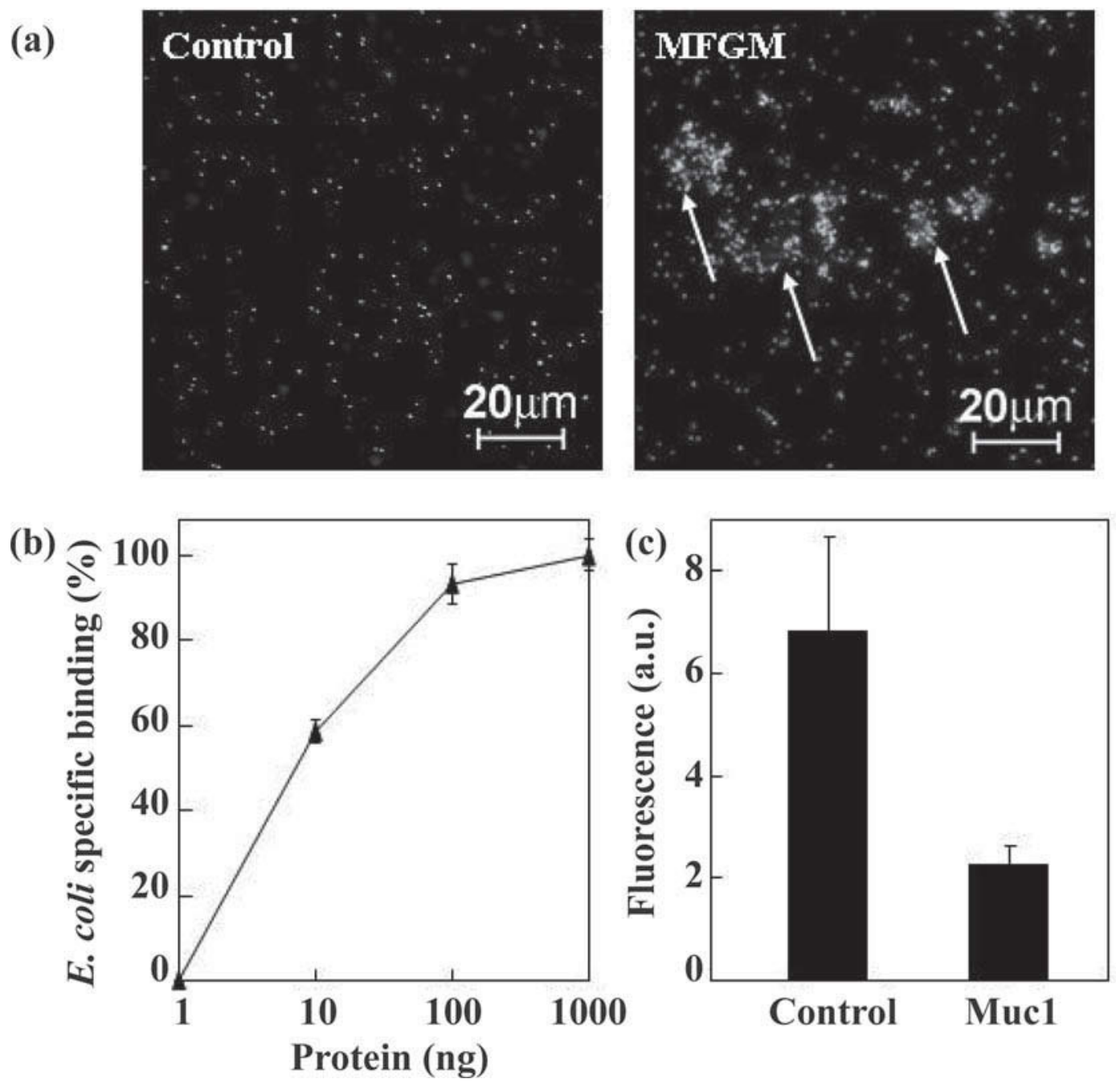

Figure 5. Muc1 binds Escherichia coli. (a) Binding of fluorescein-conjugated E. coli BioParticles (Invitrogen, Mount Waverley, Australia) to milk fat globule membrane (MFGM). Fluorescence microscopy was used to visualize the adherence of fluorescein-conjugated $E$. coli (K-12 strain) BioParticles to MFGM. Equal volumes of PBS (control) or MFGM $(500 \mu \mathrm{g} / \mathrm{mL}$ ) were incubated with $100 \mu \mathrm{L}$ of BioParticles $(1 \mathrm{mg} / \mathrm{mL})$ for $2 \mathrm{~h}$ at $37^{\circ} \mathrm{C}$. Arrows indicate the clustering of the BioParticles caused by the MFGM. (b) Direct binding of E. coli to immobilized Muc1. The direct binding of biotinylated $E$. coli to bovine Muc1 immobilized on polyvinylidene fluoride was measured. Binding was quantified by densitometry. The difference between the binding to Muc1 and the BSA control at each protein concentration was determined and then expressed as a percentage of the maximal binding. The percentage of specific binding presented in the text is the mean \pm SEM. (c) Muc1-mediated inhibition of binding of fluorescein-conjugated $E$. coli BioParticles to bovine mammary epithelial cells (MEC). Equal volumes of fluorescein-conjugated $E$. coli (K-12 strain) BioParticles $(1 \mathrm{mg} / \mathrm{mL})$ and Muc1 $(500 \mu \mathrm{g} / \mathrm{mL})$ were preincubated for $2 \mathrm{~h}$ at $37^{\circ} \mathrm{C}$ before subsequent addition of $100 \mu \mathrm{L}$ of the mixture to MEC (seeded at $1 \times 10^{5}$ cells) and further incubation for $2 \mathrm{~h}$ at $37^{\circ} \mathrm{C}$. After washing, residual fluorescence (arbitrary units; a.u.) was measured. The control used BSA. Data show the mean values from 2 experiments, each performed in triplicate. Error bars represent the SEM. 
reached in another study, but unlike the results of the current analyses, it also reported indirect evidence for a substantial quantity of N-linked glycans (Liu et al., 2005). The reasons for this latter discrepancy are unclear. Each of the 4 different major VNTR units has 7 or 8 potential O-linked glycosylation sites. The most prevalent of the 4 VNTR units also has a potential $\mathrm{N}$-linked glycosylation site. Thus, allelic variation not only defines the probable extent of O-linked glycosyla-

(a)

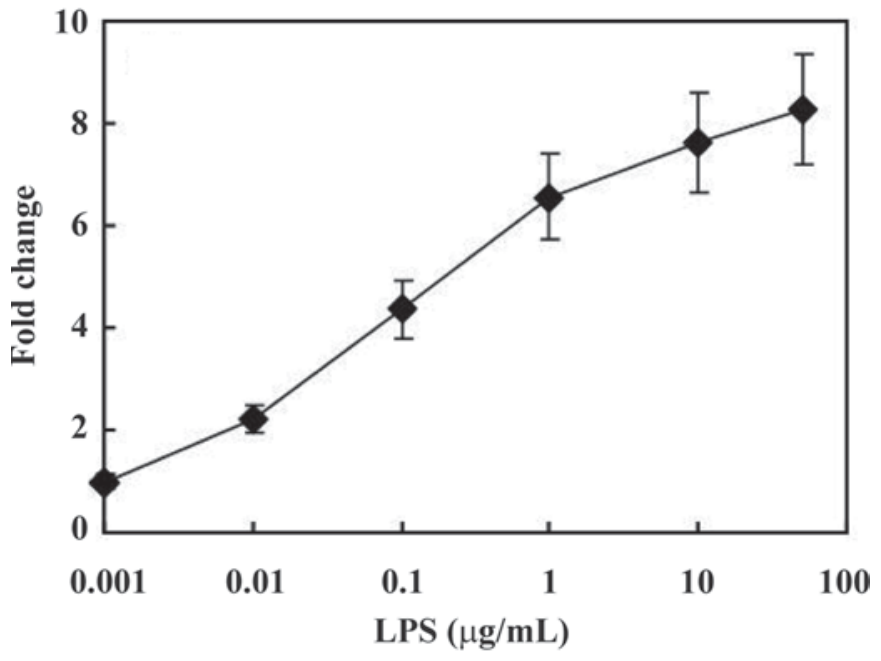

(b)

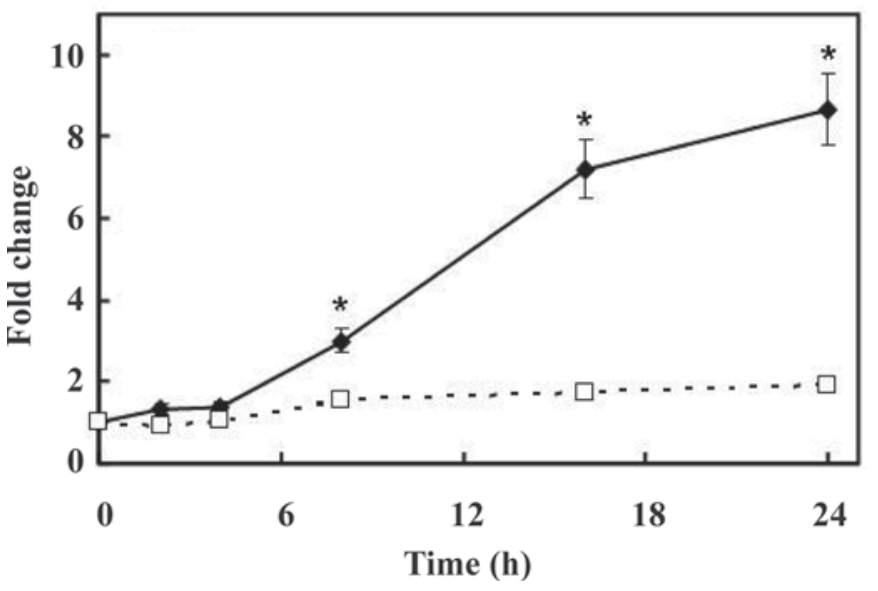

Figure 6. Muc1 mRNA expression in bovine mammary epithelial cells (MEC) incubated with LPS or lipoteichoic acid (LTA). (a) Dose response of $M u c 1 \mathrm{mRNA}$ expression in bovine MEC stimulated with LPS. Bovine MEC were stimulated with LPS $(0.01$ to $50 \mu \mathrm{g} / \mathrm{mL})$, and Muc1 mRNA levels were measured using quantitative real-time reverse transcription PCR (qRT-PCR) after $24 \mathrm{~h}$ of stimulation. (b) Time course of Muc1 mRNA expression in MEC stimulated with either LPS $(\bullet)$ or LTA $(\square)$. Bovine MEC were stimulated with $50 \mu \mathrm{g} / \mathrm{mL}$ of LPS or $20 \mu \mathrm{g} / \mathrm{mL}$ of LTA, and Muc1 expression was monitored over $24 \mathrm{~h}$ by qRT-PCR. Data are expressed as mean fold change \pm 1 SEM $(\mathrm{n}=3)$ compared with expression in unstimulated cells. ${ }^{*} P<0.05$. tion, which depends on the number of VNTR units, but also the extent and density of N-linked glycosylation, which structurally probably extends well beyond the background of the shorter O-linked oligosaccharides and may be functionally relevant.

The VNTR domain of the Muc1 protein is probably a filamentous or rod-like structure caused by several factors: 1) the abundance of Pro, which favors an extended rod-like conformation; 2) the abundance of Neu residues, which create strong repulsive charges on the surface of the protein; and 3) the immobilization by the oligosaccharides of a significant layer of water (Shi and Caldwell, 2000). The AA sequences flanking the hydrophilic VNTR domain are predicted to have a greater secondary structure and greater hydrophobicity (PepPlot; Gribskov et al., 1986). This alternating hydrophobic and hydrophilic structure of the extracellular domain may provide a nonspecific binding scaffold characterized by an array of low-affinity hydrophobic and hydrogen bonds that provide a pattern recognition function with flexibility to adapt to the surface shape of macromolecules, particles, and bacteria. It has been proposed that one of the primary functions of mucins is to protect epithelial cell surfaces from bacterial invasion. This could be achieved by the immobilization of bacteria at those surfaces through such nonspecific binding interactions with mucins (Patton et al., 1995). Subsequent shedding of the mucin by specific proteolytic processing or, in the case of the mammary gland, the formation of MFGM could allow elimination of bound bacteria in the normal fluid efflux.

The current study has added further evidence to the emerging role of Muc1 as a defensive antibacterial agent by demonstrating that it has the ability to directly bind biotinylated $E$. coli and inhibit the binding of fluorescently labeled E. coli BioParticles to bovine MEC. The binding and consequent immobilization of bacteria by Muc1 may play a key role in protecting epithelial cells from bacterial infection. Indeed, the gastrointestinal tract of Muc1-deficient mice was more easily colonized by $H$. pylori, thereby providing strong support for the role of Muc1 in protection of epithelial tissues from bacterial infection (McGuckin et al., 2007). The extensive sialylation of bovine Muc1 is probably important for its ability to bind bacteria because $\alpha 2-3$-linked Neu present on many cellular glycoproteins plays a crucial role in adherence of several bacterial species, particularly gram-negative species. Because the extent of O-linked glycosylation, including sialylation, is proportional to the number of VNTR units in the allelic variants, the marked differences in sizes between the smallest and largest Muc1 alleles (e.g., 7 vs. 23 VNTR units) may significantly affect the bacterial-sequestering activity of Muc1. Indeed, comparison of the abilities of the $G$ 
(11 VNTR) and D (16VNTR) Muc1 protein alleles to inhibit bacterial binding to MEC was consistent with this proposal, although the results were not significant (result not shown). Comparison of more divergent but rarer alleles may be informative. The ability of bovine Muc1 to sequester bacteria suggests that it is a component of the innate immune defense system. Consistent with this proposal, stimulation of bovine MEC with LPS caused rapid upregulation of the expression of Muc1 mRNA, a characteristic of many innate immune genes.

Not only does milk have great importance in providing nutrition to newborn mammals during a period of intense growth and development, but it also contains a plethora of bioactive proteins, lipids, and sugars. Milk contains several antimicrobial proteins, which presumably protect the mammary gland and also the gut of suckling young from bacterial infections (Peterson et al., 1998). This strategy has to cope with 2 biological issues. First, any antibacterial agent will be severely diluted by the volume of milk and then shed at each milking. Thus, such agents must be synthesized and maintained at high levels in milk to exert their defensive capability. To minimize energy expenditure, the agent would preferably have pleotropic functions, particularly in relation to the structural composition of milk. Second, the exposure of mammary tissue and the neonatal gut to diverse infectious agents suggests that any defensive strategies require broad specificity. Bovine Muc1 fits both criteria because it is relatively abundant in milk (but concentrated on MFGM), it may have multiple functions, and it binds a variety of bacterial species (P. Parker, L. Sando, R. Pearson, K. Kongsuwan, S. Smith, and R. L. Tellam; unpublished data).

\section{CONCLUSIONS}

The highly polymorphic genetic variants of bovine Muc1 result in substantial structural differences, at the level of both the protein and its extensive modifications with oligosaccharides, which may underlie allele-specific functional differences. The current study suggests that bovine Muc1 is as an inducible effector of innate immune responses, providing defense at the first point of contact with infectious agents through relatively nonspecific microbial-binding activity. Muc1 is likely to be a component of the outermost defensive sensory system, which helps regulate what the innate and cellular immune systems encounter, and therefore has an indirect role in the adaptive immune defense. Muc1 in milk may play a key role in preventing infection of mammary tissue and the gut of newborn suckling offspring.

\section{ACKNOWLEDGMENTS}

The authors thank S. Stockwell, B. E. Harrison, R. J. Bunch, M. B. Thomas (all CSIRO Livestock Industries, Brisbane), L. Turner (Sydney University, Sydney), J. Cavanagh (Sydney University, Sydney), and W. Barendse (CSIRO Livestock Industries, Brisbane) for donation of the bovine DNA samples; N. Spiegel (University of Sydney, Sydney) for help with milk collection; E. Lesieur (University of Queensland, Brisbane) for assistance with PCR and DNA sequencing; A. Jones (University of Queensland, Brisbane) for assistance with mass spectrometry analysis; P. Williamson (University of Sydney, Sydney) and Genetics Australia (Melbourne) for access to bovine samples for DNA extraction; Parmalat Australia Ltd. (Brisbane) for their donation of cream for isolation of Muc1; and P. Sheehy (University of Sydney, Sydney) for making the primary bovine MEC available. This research has been facilitated by access to the Australian Proteome Analysis Facility (Macquarie University, Sydney) established under the Australian Government's Major National Research Facilities program. The research was funded by the Geoffrey Gardiner Dairy Foundation (Melbourne) and Co-operative Research Centre for Innovative Dairy Products (Melbourne).

\section{REFERENCES}

Barendse, W., B. E. Harrison, R. J. Bunch, M. B. Thomas, and L. B. Turner. 2009. Genome wide signatures of positive selection: The comparison of independent samples and the identification of regions associated to traits. BMC Genomics 10:178.

Burchell, J. M., A. Mungul, and J. Taylor-Papadimitriou. 2001. O-linked glycosylation in the mammary gland: Changes that occur during malignancy. J. Mammary Gland Biol. Neoplasia 6:355364.

DeSouza, F. R. P., D. B. Dentillo, J. Meola, F. H. Biase, M. V. Andrea, P. A. Vozzi, R. B. Lobo, and L. R. Martelli. 2007. The polymorphism in $M U C 1$ gene in Nelore cattle. J. Anim. Breed. Genet. 124:42-46.

DeSouza, M. M., G. A. Surveyor, R. E. Price, J. Julian, R. Kardon, X. H. Zhou, S. Gendler, J. Hilkens, and D. D. Carson. 1999. MUC1/ episialin: A critical barrier in the female reproductive tract. J. Reprod. Immunol. 45:127-158.

Gendler, S. J. 2001. MUC1, the renaissance molecule. J. Mammary Gland Biol. Neoplasia 6:339-353.

Gribskov, M., R. R. Burgess, and J. Devereux. 1986. PEPPLOT, protein secondary structure-analysis program for the UWGCG sequence-analysis software package. Nucleic Acids Res. 14:327334.

Gupta, R., E. Jung, and S. Brunak. 2004. NetNGlyc 1.0 Server. CBS Prediction Servers. Center for Biological Sequence Analysis, Lyngby, Denmark. http://www.cbs.dtu.dk/services/NetNGlyc/ Accessed Mar. 23, 2008.

Jarman, A. P., and R. A. Wells. 1989. Hypervariable-Recombinators or innocent bystanders. Trends Genet. 5:367-371.

Jeffreys, A. J., K. Tamaki, A. MacLeod, D. G. Monckton, D. L. Neil, and J. A. Armour. 1994. Complex gene conversion events in germline mutation at human minisatellites. Nat. Genet. 6:136145 . 
Julenius, K., A. Molgaard, R. Gupta, and S. Brunak. 2005. Prediction, conservation analysis, and structural characterization of mammalian mucin-type O-glycosylation sites. Glycobiology 15:153-164.

Khatkar, M. S., A. Collins, J. A. L. Cavanagh, R. J. Hawken, M. Hobbs, K. R. Zenger, W. Barris, A. E. McClintock, P. C. Thomson, F. W. Nicholas, and H. W. Raadsma. 2006. A first-generation metric linkage disequilibrium map of bovine chromosome 6 . Genetics 174:79-85.

Kvistgaard, A. S., L. T. Pallesen, C. F. Arias, S. Lopez, T. E. Petersen, C. W. Heegaard, and J. T. Rasmussen. 2004. Inhibitory effects of human and bovine milk constituents on rotavirus infections. J. Dairy Sci. 87:4088-4096.

Lakhtin, V. M. 1995. Use of lectins in the analysis of carbohydrate moieties of glycoproteins and other natural glycoconjugates. Biochemistry (Mosc.) 60:131-153.

Levitin, F., O. Stern, M. Weiss, C. Gil-Henn, R. Ziv, Z. Prokocimer, N. I. Smorodinsky, D. B. Rubinstein, and D. H. Wreschner. 2005. The MUC1 SEA module is a self-cleaving domain. J. Biol. Chem. 280:33374-33386.

Lillehoj, E. P., H. Kim, E. Y. Chun, and K. C. Kim. 2004. Pseudomonas aeruginosa stimulates phosphorylation of the airway epithelial membrane glycoprotein Muc1 and activates MAP kinase. Am. J. Physiol. Lung Cell. Mol. Physiol. 287:L809-L815.

Liu, C., A. K. Erickson, and D. R. Henning. 2005. Distribution and carbohydrate structures of high molecular weight glycoproteins, MUC1 and MUCX, in bovine milk. J. Dairy Sci. 88:4288-4294.

Mather, I. H. 2000. A review and proposed nomenclature for major proteins of the milk-fat globule membrane. J. Dairy Sci. 83:203247.

McGuckin, M. A., A. L. Every, C. D. Skene, S. K. Linden, Y. T. Chionh, A. Swierczak, J. McAuley, S. Harbour, M. Kaparakis, R. Ferrero, and P. Sutton. 2007. Muc1 mucin limits both Helicobacter pylori colonization of the murine gastric mucosa and associated gastritis. Gastroenterology 133:1210-1218.

Patton, S., S. J. Gendler, and A. P. Spicer. 1995. The epithelial mucin, MUC1, of milk, mammary gland and other tissues. Biochim. Biophys. Acta. Rev. Biomembr. 1241:407-423.

Payne, R. W., S. A. Harding, D. A. Murray, D. M. Soutar, D. B. Baird, S. J. Welham, A. F. Kane, A. R. Gilmour, R. Thompson, R. Webster, and G. Tunnicliffe Wilson. 2005. GenStat. Release 9 Edition. VSN International Ltd., Hemel Hempstead, UK.

Peterson, J. A., S. Patton, and M. Hamosh. 1998. Glycoproteins of the human milk fat globule in the protection of the breast-fed infant against infections. Biol. Neonate 74:143-162.

Pfaffl, M. W., G. W. Horgan, and L. Dempfle. 2002. Relative expression software tool (REST) for group-wise comparison and statistical analysis of relative expression results in real-time PCR. Nucleic Acids Res. 30:e36.
Rasero, R., L. Bianchi, E. Cauvin, S. Maione, S. Sartore, D. Soglia, and P. Sacchi. 2007. Analysis of the sheep MUC1 gene: Structure of the repetitive region and polymorphism. J. Dairy Sci. 90:1024-1028.

Rasero, R., P. Sacchi, S. Rosati, E. Cauvin, and S. Maione. 2002 Molecular analysis of the length polymorphic $M U C 1$ gene in cattle. J. Anim. Breed. Genet. 119:342-349.

Raymond, M., and F. Rousset. 1995. GenePop (version 1.2): Population genetics software for exact tests and ecumenicism. J. Hered. 86:248-249.

Sacchi, P., A. Caroli, E. Cauvin, S. Maione, S. Sartore, D. Soglia, and R. Rasero. 2004. Analysis of the MUC1 gene and its polymorphism in Capra hircus. J. Dairy Sci. 87:3017-3021.

Schroten, H., F. G. Hanisch, R. Plogmann, J. Hacker, G. Uhlenbruck, R. Nobis-Bosch, and V. Wahn. 1992. Inhibition of adhesion of S-fimbriated Escherichia coli to buccal epithelial-cells by humanmilk fat globule-membrane components: A novel aspect of the protective function of mucins in the nonimmunoglobulin fraction. Infect. Immun. 60:2893-2899.

Shi, L., and K. D. Caldwell. 2000. Mucin adsorption to hydrophobic surfaces. J. Colloid Interface Sci. 224:372-381.

Spicer, A. P., G. Parry, S. Patton, and S. J. Gendler. 1991. Molecular cloning and analysis of the mouse homologue of the tumorassociated mucin, MUC1, reveals conservation of potential O-glycosylation sites, transmembrane, and cytoplasmic domains and a loss of minisatellite-like polymorphism. J. Biol. Chem. 266:15099-15109.

Strandberg, Y., C. Gray, T. Vuocolo, L. Donaldson, M. Broadway, and R. Tellam. 2005. Lipopolysaccharide and lipoteichoic acid induce different innate immune responses in bovine mammary epithelial cells. Cytokine 31:72-86.

Tachibana, K., S. Nakamura, H. Wang, H. Iwasaki, K. Tachibana, K. Maebara, L. Cheng, J. Hirabayashi, and H. Narimatsu. 2006. Elucidation of binding specificity of Jacalin toward O-glycosylated peptides: Quantitative analysis by frontal affinity chromatography. Glycobiology 16:46-53.

Thornton, D. J., K. Rousseau, and M. A. McGuckin. 2008. Structure and function of the polymeric mucins in airways mucus. Annu. Rev. Physiol. 70:459-486.

Vinall, L. E., M. King, M. Novelli, C. A. Green, G. Daniels, J. Hilkens, M. Sarner, and D. M. Swallow. 2002. Altered expression and allelic association of the hypervariable membrane mucin MUC1 in Helicobacter pylori gastritis. Gastroenterology 123:41-49.

Vuocolo, T., R. Pearson, P. Campbell, and R. L. Tellam. 2003. Differential expression of Dlk-1 in bovine adipose tissue depots. Comp. Biochem. Physiol. B 134:315-333. 